\title{
The Myth of Re-creation in Ovid's Metamorphoses
}

\author{
Ahmed Fahmy Abdel Gawad \\ Suez Canal University
}

The subject of evolution, creation and re-creation in different civilizations is an important theme. In this research the creation in Greek and Roman thought, in terms of the beginning of God's creation without an origin, where the world was complete darkness, Chaos; and then his re-creation as he began after its utter destruction will be discussed.

If this creation does not acquire some beliefs and qualities which are necessary for that life, roughness and cruelty will sustain, and the creation and the system of the world will be corrupted. These matters will be revealed by our research, beginning from the universe and the first creation, Prometheus, theft of the fire, and re-creation again through Deucalion and Pyrrha. ${ }^{1}$

If we look at the creation of the universe in Ovid and its relation to his interpretation of human creation and the early history of mankind, we will discover that the poet plays the role of the philosopher in an ironic way, the purpose of which is to present philosophy as the least degree of myth in the understanding of man and the world. ${ }^{2}$ In essence, the contrast between imagination and Ovid's formation of rationality in cosmogony does not help us absorb Ovid's own desire to support physics as a particular philosophical school or to present a theory of his own. In the first book of Metamorphoses, he proposes the mythological dimensions of the creation's myth and re-creation through poetry. ${ }^{3}$ He reduced the idea that the concept

\footnotetext{
${ }^{1}$ Paschalis, M. (2001), Semina Ignis: The Interplay of Science and Myth in the Song of Silenus, AJPh, vol. 122, p. 202; Berens, E.M. (2009), Myth and Legends of Ancient Greece and Rome, Amsterdam, p. 22.

2 Mckim, R. (1985), Myth against Philosophy in Ovid's Account of Creation, $C J$, vol.80, p.97.

${ }^{3}$ Ibid., pp. 97, 99.
} 
of the divine fabricator divinus fabricator can be compared to the creator of the physical universe in the Timaeus' dialogue ${ }^{4}$ of Plato with the interpretation and narration of the divine care that was mentioned in Diogenes Laertius in "The Life of the Philosophers" (Diog.Laert. Vitae. ph.7, 136- 137); and Cicero in "The Nature of the Gods" (Cic.ND.2.58) . As a result, Wheeler to declared that Ovidus' vision of cosmogony, creation, and re-creation was very similar to the description of the world by the Stoic speaker at Cicero (Cic.ND.2, 98 -104) in which Ovid firstly offered a panoramic view of the universe regions, its division, and a description of each area separately, taking into consideration the relative position among them. ${ }^{5}$ The interpretation of the origin of the world in Ovid in this way bears many similarities to many ancient cosmological theories, where the world appeared since its emergence in a more organized manner in terms of rationality and reality. ${ }^{6}$

In (Met.1, 1-7) Ovid tells us that before the existence of the sea, the earth and the sky ante mare et teras et quod tegit omnia caelum, the world was a total darkness or chaos quem dicere Chaos. ${ }^{7}$ It is clear that the formulation of the three divisions of the world may have seemed at first common; this was a firm idea in Greek and Roman beliefs and poetry,

\footnotetext{
${ }^{4}$ Is one of Plato's dialogues written in $360 \mathrm{BC}$. Plato deals with the subject of nature and the origin of the universe and the creator: Cf. Taylor, AE (1928), A commentary on Plato's Timaeus, Oxford, p. 23.

${ }^{5}$ Wheeler, S.M. (1995), Imago Mundi: Another View of the Creation in Ovid's Metamorphoses, $A J P h$, vol. 116, p. 96.

${ }^{6}$ Mckim, R. (1985), p. 103; Robbins ,F.E.(1913), The Creation Story in Ovid Met.1, CPh, vol.8, p. 401.

${ }^{7}$ For Chaos and Cosmogony, Cf. Hyginus, Fabulae, Sections 1-10. The term of Chaos, which was used by Ovid as a model of philosophical terms, has no echo at Lucretius, but appears at Hesiod in (Theogony.46), it is in fact a part of the philosophical vocabulary: Cf. Robbins, F.E. (1913), p. 405; Mckim, R. (1985), p. 99. On the interpretation of Ovid and Apollonius for the tripartite division of the universe ante mare et terras et quod tegit omnia caelum: Cf. Wheeler, S.M. (1995), p. 97.
} 


\section{Ahmed Fahmy Abdel Gawad}

which brings to mind the beginning of the description of Apollonius for the Orpheus ${ }^{8}$ song in "Argonautica" (Apoll.Arg. 1. 494-498). ${ }^{9}$

8 The son of Oeagrus and Calliope, the goddess of poetry, had songs to attract the charm of animals, trees and stones, and accompanied the heroes of Argo and hoped to help them overcome the dangers they faced by his music.

${ }^{9}$ Wheeler, S.M. (1995), pp. 99; 104. The description of Ovid may have been reduced in four stages; first, dividing Chaos into four regions and elements (Met. 1, 21-31); second, the arrangement of the typical physical properties (Met. I, 32-71); and third, the appearance of animals (Met.1, 72-75), and fourth, the creation of humans (Met.1, 76-88); and for comparison, Cf. the description of the world in Cicero (Cic. De Natura Deorum, 2, 98-104) .Mckim adds that Ovid here follows the philosophical view or the philosophical method in describing Creationism, and perhaps this can be compared to the pieces of Lucretius (Luc. RN.5, 443-448) and Cicero in (Cic. Tusc. 1.7.40), (Cic. N.D. 2. 91) with regard to the divisions of the world. Cf. Mckim, R., pp. 99-100; Robbins, F.E. (1913), p. 407. It seems that Ovid brings back the divine creation in the "Metamorphoses" to the evolving model of the cosmogony, which was represented in Apollonius (Apoll. Arg. 1, 494-498) and in Ovid (Fasti. 1, 105- 110) as follows:

lucidus hic aer et quae tria corpora restant, ignis, aquae, tellus, unus acervus erat.

ut semel haec rerum secessit lite suarum

inque novas abiit massa soluta domos,

flamma petit altum, propior locus aera cepit, sederunt medio terra fretumque solo.

Then the presence would consist of this enlightening air and those three elements ; Fire, water and earth; they were one mass.

Once these elements were separated because of the dissonance of their parts, The mass disintegrated and went to new places,

The firebrand rose up, and the air took the nearest place,

The earth and the valley settled in the middle of the universe.

Cf. Wheeler, S.M. (1995), p. 96.

Then Ovid confirms in (Fasti. V, 11-12) that the universe consists of the three elements of fire, water and dust:

post chaos ut primum data sunt tria corpora mundo inque novas species omne recessit opus. 
Then Ovid tells us about the God and better nature (Met. 1, 21) deus et melior...natura. ${ }^{10}$ It seems that his talk of God or better nature as an artist fulfills the expectations that the raw material of Chaos caused after the separation of the elements helped the creator form and assemble the earth in an ideal field (Met. 1, 21-23): ${ }^{11}$

Hanc deus et melior litem natura diremit.

nam caelo terras et terris abscidit undas

et liquidum spisso secrevit ab aere caelum.

The god (resolved) this dispute and better nature divided,

Where he separated between heaven and earth and between earth

And water and he rescued the clear sky from the thick air.

The influence of Lucretius on Ovid appears in the attribution of creation to fabricator god reflected by the following verses; in the first book of Metamorphoses Quisquis fuit ille deorum "which God was there among the gods" (Met. 1, 32), mundi fabricator "the fabricator of the world", Opifex rerum "the maker of things" (Met.1, 79), which Lucretius explicitly referred to in the following two verses (Luc. RN.1, 1021-1022): ${ }^{12}$

Nam certe neque consilio primordia rerum

ordine se suo quaeque sagaci mente locarunt.

Now it is certain that primary seeds are raised not by his

decision but by his preparing and by his own right mind.

After the chaos ended, once the world got the three elements, The whole universe retreated into new forms.

However, the interpretation of Ovid that the universe consists of four elements in (Met. 1, 10ff) (cold-hot-dry-wet) is similar to Empedocles (Emp. V. 172ff): Cf. Robbins, F.E. (1913), p. 403.

${ }^{10}$ Wheeler, S.M. (1995), p. 95. Mckim announces that the best deity and nature mentioned in (Met. I, 21) is an idea derived from Stoicism (Cic. ND. 1. 36-37) (Diog. Laer. 7, 136-137): Cf. Mckim, R. (1985), p. 99. For the description of the landscape at Ovid (Met. 3, 155-164): Cf. Newby, Z. (2012), The Aesthetics of Violence: Myth and Danger in Roman Domestic Landscapes, $C A$, vol. 31, pp. 349-389.

${ }^{11}$ Wheeler, S.M. (1995), p. 104. For the same idea, cf. Lucr, De Rerum Natura. 1.360.

${ }^{12}$ Robbins, F.E. (1913), p. 404. 


\section{Ahmed Fahmy Abdel Gawad}

It is not necessary that the creator is an embodied god, but perhaps he could be more than just a divine power in nature, practicing work with a strong mind, and working for a good conclusion. The factor of creation and the manner of its application, in Ovid, gives us the ability to point to the similarities between the myth of creation in Ovid and a large number of stoic writings, especially when Ovid describes to us the regions between heaven and earth (Met. 1, 45-51). ${ }^{13}$

\section{The First Creation and Anger of Jupiter}

In Metamorphoses, Ovid mentions a mythical interpretation of the universe's creation according to his Greek predecessors. After the marriage of Uranus and Gaea, then Saturn and Rhea, and the procreation of Jupiter who took over the throne, he entrusted to each god a function which is worthy of his status and ability. At that time, nothing remained but human creation and their subsequent creatures and beings. Perhaps the god of this universe who portrayed the world with this wonderful picture is the same who created a man from his seed (Met. 1, 78-79):

\section{natus homo est, sive hunc divino semine fecit}

ille opifex rerum, mundi melioris origo.

Man was born, or the fabricator of things created him

from this sacred seed, from the origin of better world.

For such creation from the sacred seed, the god of the universe did not find any one better than Prometheus and his brother Epimetheus ${ }^{14}$ to do this function. Prometheus mixed dust with water, resulting in the clay from which he formed a creature that is not very different from god (Met. 1, 8287). ${ }^{15}$ Then he made him walk on foot, and gave him a smooth skin and the

\footnotetext{
${ }^{13}$ Ibid., p. 411.

${ }^{14}$ Zeus made Prometheus, the son of Titan Iapetus and Themis, counselor for him because of his wisdom and insightful vision, and he entrusted to him and his brother Epimetheus the formation of animals and humans. Prometheus was considered the creator of man as he shaped him from clay in the form of gods and gave him some animal qualities.

15 In Hesiod's works, there are two related translations of the myth of Prometheus, one in (Theogony, 535-616) and the other in (The Days and Works, 42-1015): Cf. Paschalis, M. (2001), p. 211.
} 


\section{The Myth of Re-creation in Ovid's Metamorphoses}

ability to speak, thus the earth was transformed from a rough undistinguished mass to new forms: the forms of humans (Met. 1, 88):

tellus induit ignotas hominum conversa figuras.

The earth was transformed into unknown forms of humans.

In his book "Graeciae descriptio" Pausanias asserts that Prometheus created humans from clay: ${ }^{16}$

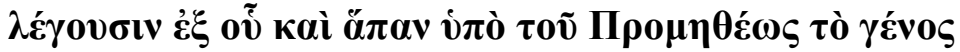
$\pi \lambda \alpha \sigma \theta \tilde{\eta} v \alpha \iota \tau \tilde{\omega} v \dot{\alpha} v \theta \rho \omega ́ \pi \omega v$.

They say that mankind was formed everywhere (from clay) by Prometheus.

However, it was mentioned in Horace's Carmina that Prometheus has mixed clay with animal parts: ${ }^{17}$

fertur Prometheus addere principi limo coactus

particulam undique desectam et insani leonis

vim stomacho adposuisse nostro.

When Prometheus was forced to add to the first brick

the separated (cut) part everywhere, and to pump in our hearts

the violence of the excited lion.

In Vergil's Aeneid ( 6, $725 \mathrm{ff}$ ), in the context of Anchesis' speech to Aeneas about the origin of the universe, we know that there is life nourishing the sky, earth, sea, moon and sun ; From this spirit the progeny of man, animal, bird and giants were created. The fire's element ignis is a basic material of the world represented by the fiery seed of gods that form the feelings of fear, desire, pain and pleasure (Aeneid , 6, 730-732): ${ }^{\mathbf{1 8}}$

${ }^{16}$ Pausanias, Graeciae descriptio, 10, 4, 4.

${ }^{17}$ Horace, Carm.1.16.13.

18 Paschalis, M. (2001), p. 214. Vergil's Aeneid depicts (7, 280-283) the horses of the progeny or the divine seeds semine ab aetherio that are exhaled flaming ignem from their nose. It is intended here the horses of Circe that she has captured by stealing furata of her father's horses - her father the sun God. Paschalis indicates that the reference here to the horses= 


\section{Ahmed Fahmy Abdel Gawad}

\section{igneus est ollis uigor et caelestis origo \\ seminibus, quantum non noxia corpora tardant \\ terrenique hebetant artus moribundaque membra.}

The semen has a fiery activity, from the seeds of divine origin

So long as it is not restricted by harmful bodies or affected

by corpses or dead members.

With this divine origin, man lived in the golden age of the first creation in peace, where there was no corruption, injustice, disease, pain, disputation, nor encounter. ${ }^{19}$ Man had children , and thus the number of human beings increased, and their consumption of the land's resources increased. The land were fruiting without plowing and people were contented. Some felt the requirement, while others had surplus. ${ }^{20}$

$=$ of Circe and the fire is an alteration of the Homeric model mentioned in the Iliad $(5,265-275)$, which explains how Anchesis stole a number of this offspring and hybridized them with his horses without the knowledge of Laomedon their owner, and gave him the birth of six horses of this offspring, and he held two for himself, and granted two for Aeneas, and the fire as a model of the celestial seed: Cf. Paschalis, M. (2001), p. 214. For Homer's influence on Vergil's Aeneid :

Cf. Brown, R.D. (1990), The Homeric Background to a Vergilian Repetition (Aeneid. 1.744 ; 3.516), AJPh, vol. 111, pp. 182-186.

For Vergil's influence on Ovid: Cf. Lamacchia, R.(1960), Ovidio Interprete di Virgilio, Maia 12, pp. 310-310. For seeds semina correlation with fire ignis or flame Flammae (Aeneid, 6, 5-6): Cf. Paschalis, M. (2001), p. 213. Robbins adds that Ovid did not have the philosophical methodology that Vergil holds. Ovid did not care to develop real interpretations of the phenomena which he enumerated, perhaps this was due to the philosophical and scientific theories familiar to the Ovid era which were the product of selectivity, causing some confusion and inconsistency of poets with the type of Ovid's poetry: Cf. Robbins, F.E.(1913), pp. 401- 402.

${ }^{19}$ Mckim, R. (1985), p. 103. For the golden age at Vergil (Georgica. I, 6063): Cf. Casali, S. (2006), Reading after Actium: Vergil's Georgics, Octavian and Rome by Christopher Nappa, $A J P h$, vol. 127, p. 613.

${ }^{20}$ Ovid, Met, 1, 101-102. As Ovid indicates that milk and Nectar were flowing in the rivers, they were the drink of the gods (Met. I, 111): 
So Vergil pointed out in Georgica $(1,121-124)$ that laziness befell the first man in the golden age, and then went on to say that this helped to kill crops by spreading rot and thorns in the lands (Georgica, 1, 150-152). ${ }^{21}$

mox et frumentis labor additus, ut mala culmos

esset robigo segnisque horreret in aruis

carduus;

Immediately it is time to work for crops, so as not to move

the evil mold to the stems and the thorns in the plowed fields.

Then the Silver age set in, followed by the Bronze Age, and the Iron Age, in which man's treatment of his fellow brother worsened, the relations between human beings and the gods were strained, and crimes scelera were revealed (Met. 1, 125-127). Obedience, modesty, trust and honesty disappeared, leaving space for greed, cheating, deceit, and sinful love to prevail (Met. 1, 129-131): ${ }^{22}$

\section{iam flumina nectaris ibant.}

Now the rivers overflow with Nectar.

${ }^{21}$ Nappa, Ch. (2002), Experiens Laborum: Ovid Reads the "Georgics" , Vergilius, vol. 48, pp. 73-74. Through the Vergilian previous verses of the "Georgica", Nappa sees that it is easy for us to grasp the understanding of Ovid for another reason for which Jupiter interfered to eliminate the first humanity, characterized by laziness and lack of effort to obtain a livelihood, and the need of the universe to create a new human of a hard and cruel origin. This reason is not accepted today by all critics and analysts, but the truth is that Ovid's presentation of the flood's story and Deucalion and Pyrrha is more complete than it is in Vergil. In Ovid, there is a direct description of the flood sent by Jupiter to destroy humanity by explicitly linking the experiment of the birth of humans from hard genus durum genus after the destruction of the first human race, which is consistent with what was mentioned in Vergil in Georgica (1, 121-124). Ovid's narrative clearly shows his knowledge of what has happened and what should happen, along with the reading of Ovid for Georgica or at least the first book, and to show that Jupiter was a god of good: Cf. Anderson, W.S.(1989), Lycaon: Ovid's Deceptive Paradigm in Metamorphosis 1, ICS 14, pp. 91-101; Paschalis, M. (2001), p. 209.

${ }^{22}$ Mckim, R. (1985), pp. 103, 105. Homer granted the gods themselves the qualities of human beings ; Although they are immortal forever, they= 


\title{
Ahmed Fahmy Abdel Gawad
}

\author{
fugere pudor verumque fidesque; \\ in quorum subiere locum fraudesque dolusque \\ insidiaeque et vis et amor sceleratus habendi. \\ In fact, modesty and trust have disappeared; \\ deceit, intrigue, violence, and sinful love \\ holding those who inhabit this place.
}

As Jupiter - the great god - watched all this from a distance, he felt bitterness and anger because crime spread and evil became a symbol of mankind and most people plunged into committing crimes. Therefore he decided to take revenge on the whole human race. ${ }^{23}$ Jupiter here in this decision represents a means of divine justice; he is good and at the same time awful. Thus, he sent a flood to sweep the first creation. Here, Ovid sees that the cause of the flood is due to the atrocity and evil of human beings and the best proofed is this the crime committed by Lycaon ( $\Lambda$ ukó $\boldsymbol{\omega} \mathbf{v}$ ) the king of Arcadia. ${ }^{24}$ Therefore, Griffin asserts that Ovid, in his speech of Jupiter's anger and his decision, has confirmed how the doubt and accusation of some that Jupiter's actions were unjust was incorrect and not based on proof. ${ }^{25}$

As for the portrayal of Jupiter's anger in the "Metamorphoses", Ovid has two main epic models: Homeric and Vergilian, and it is known that the image of Zeus in Homer's Iliad is different from his moral image in the Odyssey, and Jupiter in Vergil, is as Zeus in the Odyssey, has responsibilities as a father and a great god and human beings. Homer (Iliad, I, 528-530) declares that a nod of the head of Zeus is sufficient to shake the sides of the Olympus: ${ }^{26}$

$=$ resemble all people; they eat a lot and drink a lot. They have cruel hearts that do not respect moral principles and do not hold virtues. As a result, the dispute spread among them and they were divided into parties and camps.

${ }^{23}$ Berens, E.M. (2009), pp. $13-14$

${ }^{24}$ Griffin, A.H.F. (1992), Ovid's Universal Food, Hermathena.No.152,p. 40; Wheeler, S.M. (1995), p. 117. Segal sees that the crime of Lycaon is a profanation of the sanctities which justifies the anger of Jupiter: Cf. Segal, Ch. (2001), Jupiter in Ovid's ' Metamorphoses", Arion: JHC, vol. 9, p. 80; Nappa, Ch. (2002), p. 79.

${ }^{25}$ Griffin, A.H.F. (1992), p. 45.

${ }^{26}$ Segal, Ch. (2001), pp. 78-79. 


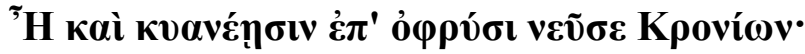

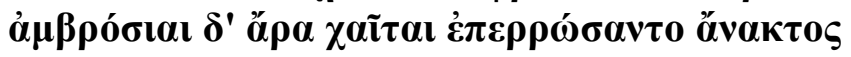

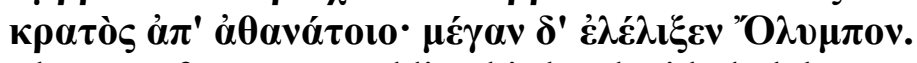
The son of Cronus, nodding his head with dark brows, where he caused a tremor in the sides of the Olympus.

Ovid kept this Olympic custom of nodding and shaking the curl of hair to indicate his loyalty to the epic tradition of his epic predecessors (Met. 1, 177180): ${ }^{27}$

Ergo ubi marmoreo superi sedere recessu, celsior ipse loco sceptroque innixus eburno terrificam capitis concussit terque quaterque caesariem, cum qua terram, mare, sidera movit.

So during (the gods') sitting in the marble hall in isolation, and from a higher place leaning on the ivory scepter, he shook the formidable hair of his head three and four times; therefore he moved the earth, the sea and the sky.

Segal believes that the adjective terrificam meaning (formidable), mentioned in previous verses describes the nod of the head and comes in the context of the superior epic style; and it is an Ovidian imitation of Homeric epic and enhancement of the personal characteristics of Jupiter during anger. ${ }^{28}$ In the "Iliad" Homer also portrays the words and signs of the Olympian ruler when he is affected by anxiety and anger in his quarrels with Hera, (Iliad, I, 519-520):

${ }^{27}$ Ovid was a faithful student of Homer, and kept his way of narration and imitated him in details to the extent that he was called "the most skillful narrator" and the best narrative poet in the Roman literature, because he transmigrated Homer and knew how to narrate his stories.

For Ovid's influence in "Metamorphoses" by Homer: Cf. Also Watkins, O.D.(1983), Ovid, "Metamorphoses", 8, 365-368, Latomus, T. 42, pp. 135138; - Olmsted, W.(1996), On the Margins of Otherness: Metamorphosis and Identity in Homer, Ovid, Sidney, and Milton, $N L H$, Vol. 27, No. 2, pp. 170-172; Segal, Ch. (1968), Homer, Vergil, Ovid, TAPHA, vol.99, pp. 43739.

${ }^{28}$ Segal. Ch. (2001), p. 80. 


\section{Ahmed Fahmy Abdel Gawad}

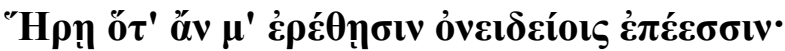

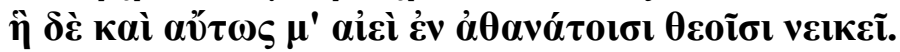

Because you make me do a struggle with the goddess Hera that will provoke my anger with its offensive words.

On the other hand, Homer reveals to us another significance of Zeus' head nod, as when he orders Thetis to leave the place, so that Hera does not note anything, Zeus himself states that the nod of his head is a sign of irrevocable promise (Iliad, I, 524-527): ${ }^{29}$

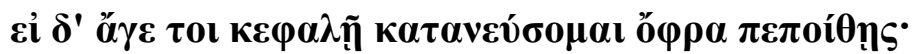

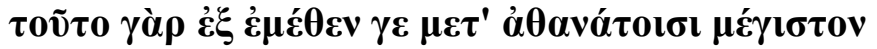

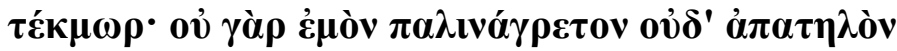

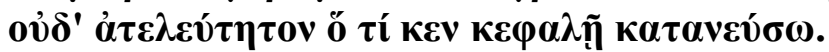

I will nod my head for you so you can be confident of that, On my part, it is a sign of sure promise between the immortals.

There is no a word to retreat or a deceptive word or a word not to be realized so long as I nodded my head.

Ovid has previously pointed out that the anger of Jupiter, which destroys human evil out of its roots, was because of injustice and corruption he saw (Met. 1, 163-164): ${ }^{30}$

\section{quae pater ut summa vidit Saturnius arce, ingemit.}

When Jupiter, the son of Saturn, saw from the highest castle

(What happened in the earth), he was enraged.

Being heart broken, Jupiter took his irrevocable decision to perish the whole human race perdendum est mortale genus (Met. 1, 188) ${ }^{31}$ After that, he sends tranquility into the hearts of some gods who are afraid of his annihilation of the human race, telling them that things will be done without damage (Met. I, 250), and that he will create new human beings from an origin that will be a miracle (Met. 1, 251-252):

${ }^{29}$ Ibid., pp. 81,83.

30 Putter, Ad. (1997), Sources and Backgrounds for Descriptions of the Flood in Medieval and Renaissance Literature, $S P h$, vol. 94, p. 150.

${ }^{31}$ Griffin, A.H.F. (1992), p. 42. 


\section{The Myth of Re-creation in Ovid's Metamorphoses}

subolemque priori

dissimilem populo promittit origine mira.

He promises of an offspring different from the previous

people and with an amazing origin.

Griffin adds that Jupiter, during the flood, was decisive and generous, taking care of right and wrong without judging emotions. ${ }^{32}$ Segal points out that the previous verses declare that Jupiter will create new human beings in a context different from the one that carries the term "survival of the fittest". ${ }^{33}$

Zeus' decision to erase the human features was because he desired to eradicate of evil and corruption by creating other people who have not known evil and corruption yet, and, thus, it is easy to teach them the principles of virtue and goodness. However, Zeus quickly feared that he would be unjust in his judgment, so he invited the council of the Olympians concilium deorum to the meeting, and they immediately obeyed him (Met. $1,166-167):{ }^{34}$

\section{et dignas Iove concipit iras conciliumque vocat: tenuit mora nulla vocatos.}

Jupiter is aroused because of the deserved anger and calls

(gods) to the meeting: The guests responded without delay.

In the session, Zeus shows how the human race was misled and how it rebelled against its creation; then he offered them his decision after his survey of human corruption. Segal indicates that although the decision of mankind destruction is the will of all gods sic uisum superis (Met. 1, 366), Ovid explains that the decision and the anger were represented in Jupiter alone (Met. 1, 253-261). Ovid also leads us to the idea that this decision

${ }^{32}$ Griffin, A.H.F. (1992), p. 41.

${ }^{33}$ Segal, Ch. (2001), p. 86.

${ }^{34}$ Griffin, A.H.F. (1992), p. 42; Lorenz, S. (2004), Dignae Iove Irae: Ovids Deucalion und Pyrrha in Juvenals erster Satire, Latomus.63, pp. 895-896. Jupiter's decision to destroy human race was identified in the council of the gods Concilium deorum after his long address (Met.1, 163-252). But in Lucretius, Jupiter did not hold a council of gods :Cf. Robbins, F.E. (1913), p. 403. 


\section{Ahmed Fahmy Abdel Gawad}

came in two stages: the first was the announcement of the crime of Lycaon, who cut off the neck of one of the worshippers with his sword, throwing his body alive in the middle of the fire and making it grilled (Met. 1, 227-229):

\section{obsidis unius iugulum mucrone resolvit atque ita semineces partim ferventibus artus mollit aquis, partim subiecto torruit igni.}

He has amputated the neck of one of the worshippers with the edge (of sword).Thus he softens some of the dead limbs which have pulses with water, throwing others to the fire to be grilled.

Jupiter has born a grudge against him, sending flames of fire to his house and burning it, but Lycaon escaped. Therefore, Jupiter metamorphosed him into the wolf fit lupus (Met. 1, 237). ${ }^{35}$

The second stage was the corruption of humans; however, Ovid gave a great importance to the story of Lycaon when he made Jupiter the narrator and connected it directly to the Deucalion flood. ${ }^{36}$

${ }^{35}$ Griffin, A.H.F. (1992), p. 47. The story of Lycaon $\Lambda \boldsymbol{v} \boldsymbol{\kappa} \alpha \boldsymbol{\omega} \boldsymbol{v}$ includes the

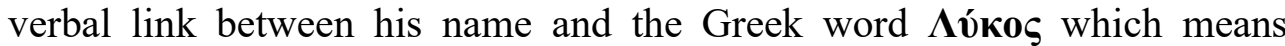
"wolf", as well as his connection with the Lycaeus Zeus' cult of Lycaeus' mountain at Arcadia. Socrates talks about this worship in the Plato's Republica (Plato, Rep. viii. 565): Cf. Griffin, A.H.F. (1992), p. 50.

${ }^{36}$ At the same time Ovid did not forget to pay our attention to the context of the creation epic by making himself the first narrator (Met. 1, $175-176$ ):

\section{hic locus est, quem, si verbis audacia detur,} haud timeam magni dixisse Palatia caeli.

This is the place where if it is being attacked with words, without fear I call it Platinus the highest heaven.

If we look at these verses, we will find that it reveals the skill of Ovid in describing Jupiter , on one hand, and explaining the paradox of Ovid's spirit around the class distinctions between the houses of the gods on the other, where Jupiter and the great gods live above heaven, while the rest of the minor gods are scattered here and there: Cf. Segal, Ch. (2001), p. 79. As Emperor Augustus was living on the Palatine Palatinum in Rome, it seemed that this phrase showed how Ovid flattered the emperors, which is also revealed in his following words (Met. I, 203-204): 
To Ovid, when the sons conspire against their parents to kill them, this means that disobeying parents has taken the place of righteousness and piety. So, Jupiter shows his anger by sending his thunderbolts that shake the Olympus (Met. 1, 154-155): ${ }^{37}$

tum pater omnipotens misso perfregit Olympum

fulmine et excussit subiecto Pelion Ossae.

Then the god destroyed the Olympus by sending his thunderbolts

which moved (the mount) Pelion from above (the mount) Ossa.

Through the previous lines, we realize that Jupiter in Ovid's Metamorphoses does not play an absurd role; rather, he has a positive effect on his knowledge of fate fata $^{38}$ and at the same time he is not destructive at all. He rejected the use of destructive means prepared by Cyclops Cyclopes $^{39}$ (Met.1, 256-259):

esse quoque in fatis reminiscitur, adfore tempus, quo mare, quo tellus correptaque regia caeli

nec tibi grata minus pietas, Auguste, tuorum quam fuit illa Iovi.

O Augustus, if the piety of your citizens for you (spread), pleasure won't be less than that for Jupiter.

Cf. Mckim, R. (1985), p. 106; Griffin, A.H.F. (1992), p. 52; Anthony S.K. (2000), Ovid's Metamorphoses, A Complete English translation and Mythological index, London, p. 25.

${ }^{37}$ Segal, Ch. (2001), p. 84.

${ }^{38}$ Zeus' obedience is essential, and at the same time Zeus himself submits to the power of fate moira, and surrender to his fatalism, which he consults in many things and submits to its will. Homer sometimes regarded Zeus and fate as one thing attributing to them the same powers (Iliad, 1, 5), (Odyssey, 11, 56).

39 The Giants Cyclopes, the sons of Uranus and Gaea, were divided into two parts: three of them with one eye in the middle of the forehead, and three with fifty heads and one hundred arms, whom Cronus imprisoned in Tartarus and then Zeus liberated to help them. 


\section{Ahmed Fahmy Abdel Gawad}

ardeat et mundi moles obsessa laboret. tela reponuntur manibus fabricata cyclopum;

Also as mentioned in fates, it will come a time, in which the sea, the earth, and the portable heaven kingdoms burn and the world's huge seats collapse.

he retracted the use of weapons made by the Cyclops.

Therefore, when Jupiter stabilizes the punishment by the flood, we feel the piety towards the gods from the survivors of this flood (Met. 1, 320329). ${ }^{40}$ In Ovid's Orpheus ' myth, all creatures bow to Jupiter power (Met. 10, 148-149):

\section{ab Iove, Musa parens, (cedunt Iovis omnia regno) carmina nostra move! Iovis est mihi saepe potestas dicta prius: \\ O my mother, the goddess of poetry (all creatures bow to Jupiter's omnipotence)! Make our songs start with Jupiter! I have been told a lot about the power of Jupiter.}

\section{The Image of the Flood at Ovid ${ }^{41}$}

All mythological stories, ancient and modern, that deal with the story of the flood are not different in details and situations, but different in substance and purpose. The flood exterminated a fictional nation that was said to live long on the Greeks' land, a nation that was characterized by a lot of strictness and harshness, and hereby carrying the cause of its destruction by destructive water. ${ }^{42}$ The most famous myth about the flood in the Greek and

${ }^{40}$ Segal, Ch. (2001), p. 86.

${ }^{41}$ There were other floods prior to Deucalion and Pyrrha 's flood, such as the flood of Nannacos, King of Phrygia, and the flood of Dardanos in the north of Greece, though less documented, and the flood of Noah: Cf. Kitchell, K.F. (1993), The View From Deucalion's Ark: New Windows on Antiquity, CJ, vol. 88, p. 342.

${ }^{42}$ Griffin sees that this interference between the mighty giants and the evil human beings is the first and the most unique in the number of the similarities between the interpretation of Ovid for Deucalion and the interpretation of the Old Testament for Noah. The infusion of the giants' role in Ovid's work is a = 
Roman world is the myth of Deucalion and Pyrrha, which Ovid succeeded, in his work "Metamorphoses", in showing its full version as the nucleus of the new re-creation of mankind. ${ }^{43}$ The most entertaining part of this myth is limited to the first book (253-437), where Ovid reconstructs the ancient Greek version of the flood legend, especially Mount Parnassus as a stable place for Deucalion and Pyrrha, and with regard to this mountain the following verse has attracted the attention and interest of most readers and writers (Met. 1, 294):

et ducit remos illic, ubi nuper arabat:

And hit by the paddles there, where it has been plowing recently.

Some scholars believe - after relying on one of the editions of the "Metamorphoses"- that the last word arabat in this verse is a spelling to present the names of the mountains in English language, and one of them is the mountain ararat, which was dedicated to Noah's Ark, mentioned in the story of the Flood (Genesis, 6). ${ }^{44}$ But it is certain that the word arabat is a brief and abbreviated form of the Latin verb (aro, arare) meaning "plow", and is not related to the name ararat. Thus, it is not likely that its use is general and comprehensive in all Latin copies of Ovid. Ryder indicates that he was unable to find another instance of the term in all models and editions that have been identified, and this confirms the idea that ararat never emerged again in Ovid's work or in the works of any other Roman poet. ${ }^{45}$

Fletcher asserts that there is no substantial intention or word play in Ovid's use of the verb arabat because it suggests a comparison between it and what is found in Genesis, especially that Ovid was following one of the

$=$ model of the reflection of the increasing human evil that eventually aroused the flood:

Cf. Griffin, A.H.F. (1992), p. 41.

It should be noted that Ryder's reference states that no Latin translation of the old testament was produced in Rome until the second century AD, so perhaps Ovid may have read the Greek translation of the Hebrew story, but there is no evidence at Ovid's interpretation that he has read the Hebrew version: Cf. Ryder, T.B. (1967), Ovid, The Flood and Ararat, $G \& R$, vol. 14, pp. 127-128.

${ }^{43}$ Griffin, A.H.F. (1992), p. 40.

${ }^{44}$ Ryder, T.T.B. (1967), p. 126.

${ }^{45}$ Ibid., p. 126. 


\section{Ahmed Fahmy Abdel Gawad}

available Greek traditions when making Deucalion land on Mount Parnassus and not Mount Ararat, with the assumption that he knew what was mentioned in the Hebrew version with regard to Mount Ararat, but doesn't restrict himself to it. ${ }^{46}$ On the other hand, if we accept the use of the word ararat as evidence that Ovid was aware of the Hebrew flood, this assumption gives place to the exploration of other elements in the flood of "Metamorphoses" related to the Hebrew flood and this has not already been done. Finally, the word ararat at the end of the Ovidian verse is used only linguistically without any metaphorical connotations. Ovid did not intend to assign a role to Mount Ararat in his legend because Deucalion and Pyrrha landed on Mount Parnassus (Met. I, 316-317). ${ }^{47}$

As for the image of the flood transmitted by Ovid to us, ${ }^{48}$ we find that Jupiter, who was about to send his thunderbolts to earth, is afraid that

${ }^{46}$ Fletcher, K.F.B. (2010), Ovidian "Correction" of the Bible Flood, $C P h$, vol. 105, pp. 209-212. Fletcher also suggests that the only explanation for this coincidence or the comparison is due to the Ovidian correction of the biblical account. Some scholars describe this correction as the poet 's unambiguous references to his Greek origin. He then goes on to present some details which contrast with his source references or he changes this source. Fletcher concludes that it is impossible to prove whether Ovid had read Moses' five books or not, but it is not unlikely to assume that some of Ovid's works are a model of Alexandrian literature, in particular "Ars amatoria"; "Remedia amoris" in which there is a reference to the word sabbata; the critics interpret it in connection to the Roman calendar and the biblical account: Cf. (Ars.am. 1, 413-416); (Rem.am. 219-220).

${ }^{47}$ Ibid., p. 210.

${ }^{48}$ For the stages of the flood and its effects on the literature of the Medieval and the Renaissance Ages, there was a great controversy about the historical situation of the floods, especially about the possibility of explaining the causes and effects. There are flood phenomena as follows:

1- Rivers overflow on their banks and spread across the land.

2- Water drowns all houses and kills inhabitants .

3- Humans escape uselessly towards the mountains.

4- Some animals ascend to the mountains while others try to stay by floating.

5- Animals and humans cry over heaven's distress.

6-Men and women embrace until their lives are over 
shooting the flaming thunderbolts would cause fire at the top of the whole sky (Met. 1, 253-255):

\section{Iamque erat in totas sparsurus fulmina terras; sed timuit, ne forte sacer tot ab ignibus aether conciperet.}

He was about to send thunderbolts all over the earth,

but he feared that the holy heaven accidentally be affected by fire.

Therefore, he changed his opinion and preferred that earth would be covered with a torrent that would sweep away all mankind (Met. I, 260261):

\section{poena placet diversa, genus mortale sub undis} perdere et ex omni nimbos demittere caelo.

He is happy to apply the dispersed punishments, to perish

human race under the waves and send out torrents from the sky.

It is known in the Greek myth that when the god's orders were issued to the winds and storms, the winds rushed from the west to meet with the winds coming from the east; and the storms spread in every direction. Zeus also opened the wells of the heaven springs and the sky continued to rain and remained uninterrupted, and all the beaches and the land were flooded . There was no piece of land left in flooded, and there was no mountain summit that has not been reached by water. Even those who have resorted to the high hilltops were hit by the flood and thus the Iron human race was being eliminated. However, in the end, the ark settled on Mount Parnassus, and when the water dried, Deucalion and Pyrrha came out of the ark, descended from the mountain, and turned into a cave that took as residence for themselves. ${ }^{49}$

So Putter points out that there are logical reasons upon which the writers and scholars of medieval and Renaissance Ages had varied interests and purposes in their reading of Ovid's Metamorphoses: Cf. Putter, A. (1997), pp. 138, 151.

${ }^{49}$ Anthony. S.K. (2000), p. 27. 


\section{Ahmed Fahmy Abdel Gawad}

In "Metamorphoses" Ovid gives us a detailed description of the event, where Jupiter collects the north winds in the Aeolus' caves ${ }^{50}$, and collects the storms that disperse the clouds, and sends the south wind that rushes with wet wings in the darkness (Met. 1, 262-264):

Protinus Aeoliis Aquilonem claudit in antris et quaecumque fugant inductas flamina nubes emittitque Notum. madidis Notus evolat alis.

Immediately he collects the north wind in the caves of Aeolus and storms that disperse the moving clouds

and he sends the south wind which rushes with its wet wings.

Jupiter does not believe that destructive factors that can be used his kingdom as he wishes are sufficient, thus, he demands the help of his brother Neptune Neptunus ${ }^{51}$, who also sends his waves and rain (Met. 1, 274-275):

Nec caelo contenta suo est Iovis ira, sed illum caeruleus frater iuvat auxiliaribus undis.

Jupiter's excited anger is not limited to what he has in his kingdom, but his brother, the god of the sea, helps (him) with helpful waves.

As a result, earth became flooded, and Ovid portrayed the catastrophic effects of the flood on earth and its inhabitants, and how Neptune himself struck the earth that split and, as a result, water flooded. The plants were uprooted, people and cattle were drowned, and houses and temples were destroyed. The whole earth became a sea (Met. 1, 283-287): ${ }^{52}$

Ipse tridente suo terram percussit, at illa intremuit motuque vias patefecit aquarum.

${ }^{50}$ In Greek and Roman mythology there are three characters named Aeolus, but Aeolus, the king of the wind that appears in the " Aeneid" and the " Odyssey", is the son of Hippotes, who was able to reserve the wind in his cave and to oblige it to obey his command. Aeolus appears in the Greek and works of Romans writers in the form of the savior because of the need of humans for the wind.

51 The god of the seas and oceans in the Roman mythology resembles Poseidon for the Greeks; he was celebrated a day called Neptunalia.

${ }^{52}$ Putter, A. (1997), p. 151. 


\section{The Myth of Re-creation in Ovid's Metamorphoses}

\section{exspatiata ruunt per apertos flumina campos cumque satis arbusta simul pecudesque virosque tectaque cumque suis rapiunt penetralia sacris.} He himself (Neptune) has struck the earth with his triple fork, the earth shook and the roads divided by the movement of water. explosive rivers flew through open fields, and at the same time, (the water was sufficient enough to flood) the trees, cattle, humans and houses and it destroyed interior rooms in their sacred temples.

One of the effects of the flood is that people, themselves, rushed to the tops of the mountains, their eyes saw fish school pending with the branches of the elm trees (Met. I, 296): ${ }^{53}$

hic summa piscem deprendit in ulmo.

He catches the fish here from a branch of an elm tree.

Through this verse, Ovid, in the "Metamorphoses," reduces how individuals begged during the flood, and those who survive from this flood will be destroyed by hunger. Thus, the human race was eliminated (Met. 1, $311-312)::^{54}$

\section{maxima pars unda rapitur; quibus unda pepercit, illos longa domant inopi ieiunia victu.}

A part was destroyed by a great wave and among those who survived the wave, those who are being overwhelmed by hunger and lack of supplies.

So, Putter points out how one can trust Ovid's ability to imagine all these details and the effects of the flood, and how floods would change the scene and human existence. ${ }^{55}$

One of the phenomena of the flood that cannot be forgotten is portraying the state of animals and their conditions during this event. Ovid is the only writer of the Greek and Roman authors who was able to display this picture. He tells us how the wolves swam among the flock of goats, and

\footnotetext{
${ }^{53}$ Kitchell, K.F. (1993), p. 344.

${ }^{54}$ Fletcher, K.F.B. (2010), p. 209.

${ }^{55}$ Putter, A. (1997), p. 152.
} 


\section{Ahmed Fahmy Abdel Gawad}

the waves carried the tigers and the lions; the strong fangs of pigs and the legs of the fast deer did not save them from the flood (Met. 1, 304-306):

nat lupus inter oves, fulvos vehit unda leones, unda vehit tigres; nec vires fulminis apro, crura nec ablato prosunt velocia cervo.

The wolf swims among the sheep, and the wave carries dust lions, the wave carries the roan tigers; neither the bright tusks

of the pig nor the legs of the fast deer intercedes.

Griffin sees that the phrase nat lupus inter oves (verse 304), "Wolf swims among sheep," is not the best choice , especially that Ovid describes Lycaon in the book, as the one who in his wicked behavior, brings the flood to mankind, and that he is a wolf who devours the sheep and tastes its blood. However, the separated links may have been one of the methods Ovid used to link different stories in one narrative. Therefore, it was not only Lycaon's metamorphosis to a wolf the only punishment he got, but also he drowned alongside all the other living creatures during the flood. ${ }^{56}$ Nevertheless, Virgil pointed out in Georgica ( 1,130$)$ "praedarique lupos iussit " that Jupiter had ordered wolves to hunt him. ${ }^{57}$

\section{Epic of Re - Creation}

Ovid reminds us of Jupiter's first creation when he describes the offspring created by the earth from the blood of the plundered giants, that had human qualities; but soon this blood excited in their hearts and they characterized by violence (Met. I, 157-162): ${ }^{58}$

perfusam multo natorum sanguine Terram immaduisse ferunt calidumque animasse cruorem et, ne nulla suae stirpis monimenta manerent, in faciem vertisse hominum; sed et illa propago contemptrix superum saevaeque avidissima caedis et violenta fuit.

It has been created a land covered with the blood

${ }^{56}$ Griffin, A.H.F. (1992), p. 45.

${ }^{57}$ Nappa, Ch. (2002), p. 79.

${ }^{58}$ Griffin, A.H.F. (1992), p. 42. 


\section{The Myth of Re-creation in Ovid's Metamorphoses}

of many children (Giants)

and (the gods) breathe life in the warm blood

To keep the traces of their seed (creation),

This has been transformed into human form; but this offspring

created from plundered blood was marked by greed and violence.

Here, Ovid considers the moral degeneration represented by the absence of truth, sincerity, honesty, and spread of deceit and betrayal as features of human behavior in the Iron Age (Met. 1, 127-131): ${ }^{.9}$

\section{de duro est ultima ferro. \\ protinus inrupit venae peioris in aevum \\ omne nefas: fugere pudor verumque fidesque; \\ in quorum subiere locum fraudesque dolusque \\ insidiaeque et vis et amor sceleratus habendi. \\ Finally there is an (Age) of iron steel \\ and immediately all the elements of the reservoir \\ in life emerged in the vein of the worst: \\ where modesty, truth and honesty disappear; \\ whereas cheating, deception, \\ wiles, violence and sinful love take their place.}

While describing the stages of the beginning of the flood and its development, Ovid also describes its stages, and how Jupiter emitted the winds of the north clearing fog. Then the sky appeared clear and the earth appeared, the waves subsided, and life returned to its first state redditus orbis erat (Met. 1,348). Then Ovid goes on to describe the epic of Jupiter's creation of a second generation, unlike the generation of crimes, cruelty, impiety, and betrayal. This narrative epic begins with the description of the highest Mount of Parnassus that has two summits touching the stars, the mountain that the ark of Deucalion and Pyrrha landed on (Met. 1, 316 $318):{ }^{60}$

${ }^{59}$ Griffin, A.H.F. (1992), p. 42.

${ }^{60}$ For dualism of characters such as Deucalion and Pyrrha, Echo and Narcissus, Orpheus and Euridyce in Ovid's Metamorphoses: Cf. Stirrup, B.E. (1976), Ovid's Narrative Technique: A Study in Duality, Latomus. 35, 


\section{Ahmed Fahmy Abdel Gawad}

mons ibi verticibus petit arduus astra duobus, nomine Parnasos, superantque cacumina nubes. hic ubi Deucalion.

There it is a high mountain with two tops (reaching) the stars, its name is Parnassus; the two tops invade the clouds. here, where Deucalion (stays).

They alone survived the flood. So, Ovid portrayed them as the faithful worshippers of the gods, and as a result, their lives have been saved (Met. 1, 325-327): ${ }^{61}$

\section{et superesse virum de tot modo milibus unum, et superesse vidit de tot modo milibus unam, innocuos ambo, cultores numinis ambo. \\ And he sees the survival of one man among all thousands of men, And the survival of one woman among all thousand women, And both of them are virtuous, worshippers of the gods.}

In the previous verses, Ovid refers to the secret word of the survival of Deucalion and Pyrrha, which lies in piety pietas and sanctification of the gods; these qualities give humanity another chance of life. ${ }^{62} \mathrm{He}$ also succeeds in showing fears and worry about the fate of the human race represented by the surviving couple, when Deucalion addresses his wife of the difficulties that faced them (Met. 1, 351-355): ${ }^{63}$

o soror, o coniunx, o femina sola superstes, quam commune mihi genus et patruelis origo, deinde torus iunxit, nunc ipsa pericula iungunt, terrarum, quascumque vident occasus et ortus, nos duo turba sumus;

$\mathrm{O}$ my sister, $\mathrm{O}$ my wife, $\mathrm{O}$ the only surviving woman, Who (remained) for me from the human race and the

pp. 97-107; Griffin, A.H.F. (1977), Ovid's Metamorphoses, G\&R, vol. 24, pp. $57-70$.

${ }^{61}$ Segal, Ch. (2001), p. 86.

${ }^{62}$ Griffin, A.H.F. (1992), p. 52.

${ }^{63}$ Ibid., p. 53. 


\section{The Myth of Re-creation in Ovid's Metamorphoses}

origin of the cousins,

after being bound by the bond marriage, we face the risks,

which we see on the earth and the sea; we are both in distress.

Born sees that the myth of re-creation based on Deucalion, the representative of the male gender, and Pyrrha the representative of female gender, reminds us of two elements of metals, gold and silver. ${ }^{64}$ The narratives about the name of the mountain that Deucalion and Pyrrha resorted is not clear; whether being Parnassus, Aetna or Athos; ${ }^{65}$ however , Hyginus chooses Aetna. ${ }^{66}$

omne genus humanum interiit praeter Deucalionem et Pyrrham, qui in montem Aetnam.

All human race perished except Deucalion and Pyrrha who (stayed) over mount Aetna.

And Servius chooses Athos: ${ }^{67}$

Pyrrha et Deucalione, qui in monte Atho liberati sunt.

By Pyrrha and Deucalion, who took their freedom over Mount Athos.

However, what is fixed in this narrative is Mount Parnassus

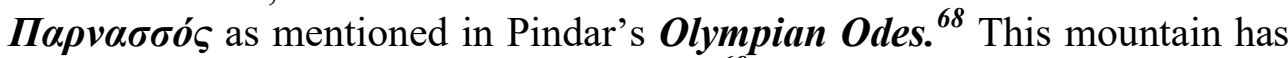
its own holiness; the goddess Themis ${ }^{69}$ who had temples in which prophecies were issued, is associated with the mountain of Parnassus. This is evident in the verses that narrate how Deucalion and Pyrrha went to

${ }^{64}$ Born, L.K. (1934), Ovid and Allegory, Speculum, vol. 9, p. 378.

${ }^{65}$ Griffin, A.H.F (1992), p. 40.

${ }^{66}$ Hyginus, Fabulae, 153, 1, 2-3.

67 Maurus Servius Honoratus, In Vergilii Bucolicon, 6,41,11. Cf. also. Maurus Servius Honoratus, In Vergilii Aeneidos Libros, 12, 701, 1-2.

${ }^{68}$ Pindar, Olympian Odes, 9, 43.

${ }^{69}$ She is the daughter of Uranus and Gaea, and although she is one of the Titans who are inimical to Zeus, but is subdued to his rule and is a symbol of law, discipline and justice; she is sometimes considered a goddess of prophecy. She also has revelation on Mount Parnassus which she abandoned later on to Apollo in Delphi. 


\title{
Ahmed Fahmy Abdel Gawad
}

consult the goddess who used to give prophecies at the versant of mount Parnassus (Met. 1, 379-380). ${ }^{70}$

\author{
dic, Themi, qua generis damnum reparabile nostri \\ arte sit. \\ O Themis, tell us how your prophesy can compensate what \\ has been done with our human race.
}

Because Deucalion was worried after the storm calmed down, he feared that he and his wife would face the same destruction that perished the rest of mankind (Met. 1, 356-357):

\section{haec quoque adhuc vitae non est fiducia nostrae certa satis.}

There is not enough confidence so far that this matter also (infects) our lives.

Deucalion and Pyrrha are unique humans; they have survived a universal catastrophe, and this is more evident when Deucalion mentions that re-creation happened through them again (Met. 1, 365): ${ }^{71}$

\footnotetext{
70 There is another narrative of the Greek legend that Deucalion and Pyrrha arrived after long roaming of the temple of Delphi. The righteous couple advanced towards the ruined Holy of holies, and prayed for the gods to reestablish the earth again, directing their prayers to the inhabitants of the ancient temple. If the earth is re -established again we will offer sacrifices and judge in justice and teach wisdom for people. Zeus watched everything and followed every movement, having been impressed by the invocation of Deucalion and his wife Pyrrha, then he moved to the temple until he reached the Holy of holies. He appeared in front of them and decided to create a virtuous generation that doesn't know evil or corruption, and decided to reestablishe the earth again with good people; then he ordered them, " you and your wife come out of the temple, put a veil on your face and a veil on her face, and then threw the bones of your mother from above your back as you marched. So, the earth will live and will be re-established according to Zeus ' will. Cf. also. Berens, E.M. (2009), p. 14.

${ }^{71}$ Green, M. (2001), Softening the Stony: Deucalion, Pyrrha, and the Process of Regeneration in "Paradise Lost", $M Q$, vol. 35, p. 9.
} 


\section{The Myth of Re-creation in Ovid's Metamorphoses}

nunc genus in nobis restat mortale duobus.

Now the survival of the human race lies in us.

The epic of re-creation lies in the salvation of one man and one woman and their survival after the legend of the flood culminates and the fulfillment of god's will is fulfilled. This happened because, as we have already pointed out, Deucalion and Pyrrha were pious as mentioned in Ovid (Met. 1, 325327). ${ }^{72}$

When we pursue the myth of creation through them, we find the story of Deucalion and Pyrrha and the boat which anchorages above Mount Parnassus, after the end of the flood, where an offspring of stone is created, and this first appears in Pindar's Olympic Hymns (9, 42-45):

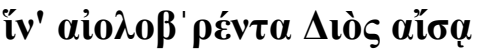

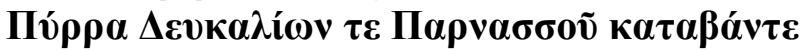

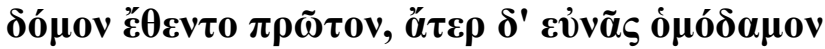

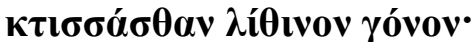

Up on the order of Zeus, the lightning thunderbolts Prince,

Deucalion (with his wife) Pyrrha came from Parnassus

They founded their first home, and without a marriage

They created a united progeny of rocky offspring.

Griffin sees that Pindar in the "Olympic Hymns" elevates the honor of this progeny "human of stone" especially when Pindar refers to the descent of the ancestors of Apharmostos ${ }^{73}$ with their iron shields from this offspring (Olympic Hymns, 9, 53-54) ${ }^{74}$. The verses mentioned above refer to the link between Deucalion and Pyrrha, stone offspring and the universal flood caused by Zeus, the thunderbolts Prince. Pindar reduced the myth in these previous verses to the idea that Deucalion and Pyrrha ascended above Parnassus, and then the water flooded the earth. However, with the power of Zeus, the flood suddenly dried and out of that seed descended Lokrians

${ }^{72}$ Fletcher, K.F.B. (2010), p. 211.

${ }^{73}$ A Citizen of the city of Opus in central Greece was a famous wrestler who achieved great success in the Greek Games.

${ }^{74}$ Griffin, A.H.F. (1992), p. 39.

Compare which mentioned in Ovid (Met. 1. 244-437); in Apollodorus. (1.7.2). 


\section{Ahmed Fahmy Abdel Gawad}

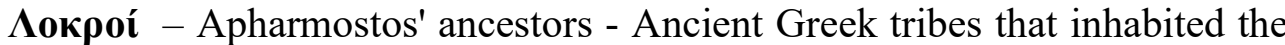
region of Locris in central Greece around Parnassus ${ }^{75}$. The creation of humans from stones through the force of obstetric or metamorphosis is carried out in the three stages (mud - clay - blowing the soul). This creation is a state of immortal myth; because the stones will tender and then take pictures of human structures like statues, and then they are covered by meat (Met. 1, 400-413) ${ }^{76}$ :

saxa (quis hoc credat, nisi sit pro teste vetustas)

ponere duritiem coepere suumque rigorem

mollirique mora mollitaque ducere formam.

mox ubi creverunt naturaque mitior illis

contigit, ut quaedam, sic non manifesta videri

forma potest hominis, sed uti de marmore coepta

non exacta satis rudibusque simillima signis,

quae tamen ex illis aliquo pars umida suco

et terrena fuit, versa est in corporis usum;

quod solidum est flectique nequit, mutatur in ossa, quae modo vena fuit, sub eodem nomine mansit, inque brevi spatio superorum numine saxa missa viri manibus faciem traxere virorum et de femineo reparata est femina iactu.

If the stones (who believed in this, if it was not for the testimony of seniority of creation)

75 John Milton mentions in "Paradise Lost" in (Book 11, verses 10-14) to Deucalion and Pyrrha:

"Myths have spoken a couple of the ancients, Deucalion and his wife Pyrrha,

who raised the invocation to return the human race to existence after the sinking, standing in worship and piety in the temple of Themis"

The combined points between the interpretation of Ovid and the scene of "Paradise Lost" are that Deucalion and Pyrrha, like Adam and Eve, are the only remaining human beings. Adam and Eve, like the Ovidian couple, pray in the rainy world :Cf. also. Green, M. (2001), pp. 9-10; Olmsted, W. (1996), pp. 173.

${ }^{76}$ Green, M. (2001), pp. 10-11; Wheeler, S.M. (1995), p. 116. 


\section{The Myth of Re-creation in Ovid's Metamorphoses}

With their solid condition begin their hardness without delay and take a form.

Immediately when they are created, the better nature dominates this, Indeed, this has not been clearly seen

And how the shape can (turn) into human beings, but this began using marble statues

It is not sufficiently well-done in its sculpture, but it is very similar to the signs of (humans)

However, in these shapes there is a wet part as juice

It has the clay of the earth, and soon it becomes a body;

It is solid and cannot move, then turns into bones

In the same way the vein appears, which remains under the same name, After a while the largest blocks of stones

which are thrown by the man turn into bodies of men with hands

those thrown by women restore women's status.

Through the analysis of the previous verses, the phrase "naturaque mitior" means "better nature" (verse 403) and it is one of the necessary elements for the implementation of that miracle, and treatment of the problem of human resurrection after its deserved destruction, where the two sexes cared for each other. In this statement, the differences between the two genders show the masculine and feminine qualities mainly and distinctly ${ }^{77}$. Thus, the creation of animals and humans belong together to "the myth associated with fertility" ${ }^{18}$.

In fact, the narrative does not differ around the creator of this creation Great god - but differ about the nucleus of creation or the people who are considered the cause of the creation of a new human being. In the Iliad ( 24 , 611) Homer mentions that Zeus himself - the son of Cronus- is the god who turned all the people into stone:

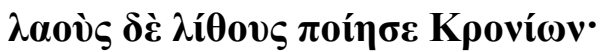

Where the son of Cronus turned all the people into stones.

${ }^{77}$ Green, M. (2001), p. 11.

${ }^{78}$ Paschalis, M. (2001), p. 205. 


\section{Ahmed Fahmy Abdel Gawad}

In contrast, one of Hesiod's fragments (Fr. 234, 1-3) asserts that Zeus turned stones into men, and this creation provided us with the ancestors of the Leleges ${ }^{79}$ people $\Lambda \boldsymbol{\varepsilon} \lambda \boldsymbol{\varepsilon} \gamma \boldsymbol{\varepsilon} \varsigma^{80}$ :

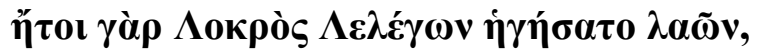

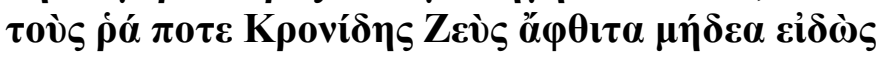

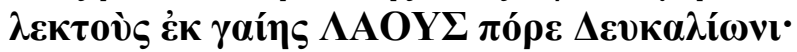

So, indeed, the Leleges people descended from Locros.

It is known that immortal Zeus is the son of Cronus

He made Deucalion a basis for the creation of humans from the earth's stones.

Therefore, Griffin asserts that Hesiod is the first who refers to Zeus' association with the transformation of stones into humans; whereas there is no reference in Hesiod to the flood, and there is no evidence that Hesiod created a connection between Zeus' humans transformed from stones and flood. Farnell declares that the connection between Deucalion and Pyrrha, and the flood, seems to have come later to Hesiod. ${ }^{81}$

As Vergil refers in Eclogues Eclogae to Pyrrha's creation of a human race from stones; where Selenus' poem about creation is close to Pyrrha's myth (Eclogae, 6, 31-42): ${ }^{82}$

\section{Namque canebat uti magnum per inane coacta semina terrarumque animaeque marisque fuissent et liquidi simul ignis; ut his ex omnia primis, omnia et ipse tener mundi concreuerit orbis; tum durare solum et discludere Nerea ponto}

\footnotetext{
${ }^{79}$ Leleges were one of the pre-Hellenic aboriginal peoples of the Aegean littoral.

${ }^{80}$ Griffin, A.H.F. (1992), p. 39.

${ }^{81}$ Ibid., p. 39. For connection between the words $\lambda \tilde{\alpha}$ o $\varsigma$ "human race people" and $\lambda \tilde{\alpha} \alpha \varsigma$ "stone": Cf. Haig, S. (1965), Andre Pieyre de Mandiargues and "Les Pierreuses", FR, vol. 39, p. 279; Paschalis, M. (2001), p. 207.

${ }^{82}$ Wheeler, S.M. (1995), p. 95; Paschalis, M. (2001), p. 206. Cf. also. Thomas, R.E. (1986), Virgil's Georgics and the Art of Reference, HSPh 90, pp. 171-198.
} 
coeperit et rerum paulatim sumere formas: iamque nouum terrae stupeant lucescere solem، altius atque cadant summotis nubibus imbres، incipiant siluae cum primum surgere cumque rara per ignaros errent animalia montis. hinc lapides Pyrrhae iactos,

Indeed he was singing how the first seeds of the earth, The air and the sea had been assembled into great space

The same thing for water and fire; from these first elements arose all (origins)

And how it spread all over the world,

Then the earth began to dry up and Nereus was out in the sea

Gradually all other things took their forms;

How does the earth admire now the rise of the new sun, And how do the rains fall off clouds,

And when do forests begin their first appear

And the rare animals wander above the mountains they do not know it.

From here he refers to Pyrrha's thrown stones

It is assumed that Pyrrha's thrown stones Pyrrhae iactos mentioned in Selenus' song match, to some extent, what mentioned in Vergil's Georgics (Georgica, I, 104), in particular semina... iacta, which reminds us of Ovid's use of the word iacio in the same meaning referring to throwing the seeds (Heroides, 6, 11-12): ${ }^{83}$

seminibus iactis segetes adolesse virorum

inque necem dextra non eguisse tua.

From the thrown seeds arise the harvest of men

Whose killing was in no need of your right arm.

Paschalis reference to the origin of the universe in the Song of Selenus reminds us of Lucretius' skill in De Rerum Natura (1, 250-264; 2, 991$1022 ; 5,783-825)$. These verses explain that all forms of life originated from the mother earth Because it became fertile by the seeds celesti ...semine (De Rerum Natura, 2, 991) by the father- the sky- sowed through rain imbris, umor under the umbrella of the warm sun sol, calor ${ }^{84}$ It seems

${ }^{83}$ Paschalis, M. (2001), p. 205.

${ }^{84}$ Ibid., p. 207. 


\section{Ahmed Fahmy Abdel Gawad}

clear through the passages in Georgica and De Rerum Natura, that natural philosophy and mythology are not only intertwined, but also shares common ideas. In the previous verses in (Eclogae, 6, 37-40) we find that the beginning of life has been associated with the two elements mentioned above the sun (temperature) sol and rains (humidity) imbres, where the humidity of earth moves higher in the form of clouds producing rainfall altius atque cadant summotis nubibus imbres. Then the rain and sun temperature lead to the emergence of forests and animals that come out of the earth and, thus, create the first form of landscape. ${ }^{85}$ It seems that Ovid here imitates the Orpheus and Selenus' songs in the idea of the origin of the universe through the formation of the model of philosophical prose, which stimulates the theory of the composition of the universe by the skill and making of God. ${ }^{86}$

Nappa says he will not try to lay a logical basis for Ovid's use of Vergil's subject in Georgics. It is just an attempt to shed light on Ovid's reading of Deucalion's reference mentioned in Vergil's Georgica (I, 61$63):^{87}$

quo tempore primum

Deucalion uacuum lapides iactauit in orbem, unde homines nati, durum genus. ergo age, terrae.

At this time when Deucalion has thrown the stones at first

On the empty ground, a human being was born of a dry rock genus.

But it is worth mentioning that the important features of Deucalion's myth in Vergil not only lies in its renewal, but also in its being a reference to the first human rocky creation. This is confirmed by Ovid's simulation of these previous verses in (Met. 1, 414-415) attributing all of the human forms of violence and cruelty to this harsh genesis: ${ }^{88}$

${ }^{85}$ Ibid., p. 207.

${ }^{86}$ Wheeler, S.M. (1995), p. 96.

${ }^{87}$ Nappa, Ch. (2002), vol. 48, p. 72; Paschalis, M. (2001), p. 206. Paschalis asserts that Virgil's reference in Georgics to the myth of Deucalion lies in his desire to describe this myth as an agricultural myth that speaks of the growth of primitive crops in similar climatic conditions, and the use of tools such as plows: CF. Paschalis, M. (2001), p.206.

${ }^{88}$ Segal, Ch. (2001), p. 86; Kitchell, K.F. (1993), p. 344. 


\title{
The Myth of Re-creation in Ovid's Metamorphoses
}

\author{
inde genus durum sumus experiensque laborum \\ et documenta damus qua simus origine nati. \\ We belong to the genus of a solid and cruel nature \\ And we must provide proofs for the origin of our creation.
}

The retention of the couple, Deucalion and Pyrrha, symbolizes that the true nature of man or human beings in general is divine rationality as a logic or as a source of interpretation and every thing falls under the favor of god. ${ }^{89}$ It is clear from Ovid's previous phrase genus durum "hard genus" in (Met. 1, 414) that it is an imitation of Virgil's phrase durum genus "rock genus" (Georgica, 1, 63). The two phrases describe the human race and its first genesis of stones. Here, the similarity between Ovidian and Vergilian texts makes us assured that this is a synonym. ${ }^{90}$ After Deucalion sowed durum genus "hard or rough genus", which means the rocks, there was an intended purpose of this creation that depends on hardness; this means the vanishing of weakness, laziness and indifference, characterizing the first creation in the golden age and the absence of movement and activity to survive. $^{91}$

Warmness and severe heat are the basis of life, as is the case with fire and water. In spite of their antagonism, our lives are maintained because of the warmth of fire and the moisture of water ; this harmony based on the contrast between warmth and moisture is the secret of life on earth (Met. 1, 430-433):

quippe ubi temperiem sumpsere umorque calorque, concipiunt, et ab his oriuntur cuncta duobus, cumque sit ignis aquae pugnax, vapor umidus omnes res creat, et discors concordia fetibus apta est.

Certainly when temperature results from warmth and moisture,

${ }^{89}$ Mckim, R. (1985), 106.

${ }^{90}$ Nappa, Ch. (2002), p. 73. The phrase of Ovid et documenta damus qua simus origine nati (Met.1, 415) confirms the idea that the hard feature of the human race gives evidence of the origin of its genesis from the rocks. According to Ovid, the new human race is hard and rough, as Vergil pointed out in the Georgics.

91 Barnes, C.L.H. (2007), Reading after Actium: Vergil's Georgics, Octavian, and Rome by Christopher Nappa, Vergilius, vol. 53, p. 188. 


\section{Ahmed Fahmy Abdel Gawad}

By these two elements emerges life,

Let the same conflict for fire and water be, where the wet steam makes

All things grow; this variation is the secret of compatibility between

the two elements.

Fire and water must be fighting ignis aquae pugnax (Met. 1, 432), such as the elements in Chaos pugnabant (Met. 1, 19) to create the necessary wet steam for life vapor umidus omnes, res creat (Met. 1, 432-433). ${ }^{92}$ Pyrrha's selection in Vergil's Eclogues may be due to her name which represents the

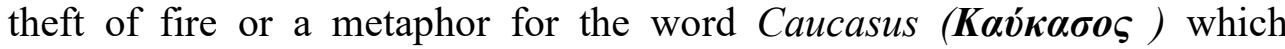

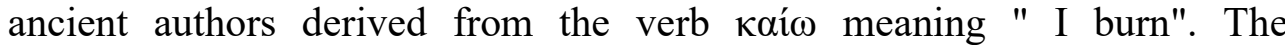
connection here is due to the derivation of Pyrrha's name from $\pi$ í $\rho$ meaning "fire". The Roman poets dealt with Pyrrha's fire in different ways; Horace in Epodes (1, 2, 1-6) for instance makes people fear to return to the time of Pyrrha, the meaning intended here is reference to the flood. ${ }^{93}$

Ovid exploits this derivation in Heroides to play on words and express "fire love"; Pyrrha enchants the love songs for Deucalion, in the same time Deucalion is saved from the fire:

\section{hinc se Deucalion Pyrrhae succensus amore misit, et inlaeso corpore pressit aquas. \\ nec mora, versus amor fugit lentissima mersi pectora, Deucalion igne levatus erat. ${ }^{94}$}

Here, Deucalion himself has fallen in love with Pyrrha, He resisted upon the water with an indifferent body.

Without any delay love escapes towards very lazy hearts

Where Deucalion is saved from the fire.

Juvenal also refers to the warm life and the creation of human beings from stones, when the warmth of Pyrrha generated at first a warm life that has turned into an erotic fire. ${ }^{95}$ Lorenz points out that Juvenal in Saturae (1, 81-85) considers the myth of Deucalion and Pyrrha as the beginning of the

\footnotetext{
${ }^{92}$ Mckim, R. (1985), p. 107.

${ }^{93}$ Paschalis, M. (2001), pp. 207-208.

94 Ovid. Her. 15. 167-170.

${ }^{95}$ Paschalis, M. (2001), p. 208.
} 
history of mankind, in which he relies on what is mentioned in Ovid's Metamorphoses. $^{96}$

ex quo Deucalion nimbis tollentibus aequor

nauigio montem ascendit sortesque poposcit

paulatimque anima caluerunt mollia saxa

et maribus nudas ostendit Pyrrha puellas, quidquid agunt homines.

Since that moment the rain clouds have been floating over the sea

Deucalion climbs the mountain in a boat and asks for oracles

The soft stones are gradually filled with warm spirit

Pyrrha shows naked girls like nymphs,

They are really turning into human beings.

Miller adds that the myth of Deucalion and Pyrrha here in Juvenal's work seems to be a type of story written by a poet who likes the Alexandrian taste of Callimachus in Hymns (Call.H. 3, 4-8), ${ }^{97}$ as well as the themes that involve transformation. Griffin adds that it is interesting to find Ovid in the first book of the "Metamorphoses" following the literary program recommended by Vergil in the sixth book - the sixth song of the Eclogues. He talks about cosmic nature and imitation referring to the myth of Deucalion and Pyrrha as mentioned in Eclogae $(6,42)$ hinc lapides Pyrrhae iactos. $^{98}$

Ovid's Deucalion summarizes the creation of men from stones when he declares to his wife Pyrrha that he wishes to be able to blow the spirit into the clay his hands have made. The survival of human race is commanded by him and his wife; therefore, the will of the gods is combined between them (Met. 1, 363-366): ${ }^{99}$

o utinam possim populos reparare paternis artibus atque animas formatae infundere terrae! nunc genus in nobis restat mortale duobus.

${ }^{96}$ Lorenz, S. (2004), pp. 92-93.

${ }^{97}$ Miller, J.F. (1993), Ovidian Allusion and the Vocabulary of Memory, MDTC, vol. 30, p. 164.

${ }^{98}$ Griffin, A.H.F. (1992), p. 40.

${ }^{99}$ Anthony, S.K. (2000), pp. 29-30. 


\section{Ahmed Fahmy Abdel Gawad}

sic visum superis: hominumque exempla manemus'.

I wish I could restore humans

With parental skills and to blow the spirits in the earth's clay!

Now the survival of human race is our responsibility.

This is the vision in the highest heaven: We remain models for humans.

Then, they go to the altar of the holy goddess Themis as mentioned before. ${ }^{100}$ They beg the goddess saying, "we are pleading for the goddess to respond to our sincere prayers and to repair what has happened to the human race". So, the goddess felt pity for them and uttered this prophecy; that they leave the temple, put a cover on their heads, and dilute those belts that tighten their clothes. Then, she said to them "Leave behind you the bones of your great mother" (Met. 1, 381-383): ${ }^{101}$

"discedite templo

et velate caput cinctasque resolvite vestes.

ossaque post tergum magnae iactate parentis"

Go out of the temple and put covers up the head, and loosen the clothes. After that throw

behind your back the bones of great mother" .

The mother earth brings by force all living and non-living beings, including men (compare what mentioned in ( Lucr. De Rerum Natura, 5. 821-825). The cosmic relationship between natural philosophy and mythology in the cosmic section is not merely a stylistic feature but reflects a sort of fulfillment of the promise between Lucretius in science and Hesiod in myth, especially with regard to cosmogony. ${ }^{102}$

Therefore, the existence of long-lived animals was recently emerging from the fact that Greek and Roman legends were in contrast to their predecessors. ${ }^{103}$ At the end of the myth of human creation, Ovid tells us about the creation of new patterns, unfamiliar to the earth. When the sun in the heavens emitted warmth to the earth mudded by the flood, many offspring spread on the earth. According to the scientific vision of creation

${ }^{100}$ Nappa, Ch. (2002), p. 77.

${ }^{101}$ Green, M. (2001), p. 10.

102 Paschalis, M. (2001), p. 205.

${ }^{103}$ Kitchell, K.F (1993), p. 342. 
in the "Metamorphoses", the earth autonomously created other animals (Met. 1, 416-417):

cetera diversis tellus animalia formis sponte sua peperit.

the earth autonomously created the other animals

from different forms.

This spontaneous generation of animals is created through the discordant harmony of the elements discors concordia (Met. 1, 433): ${ }^{104}$

res creat, et discors concordia fetibus apta est.

He creates things; this results from the discordant harmony of the elements.

Creatures came with familiar patterns, and others came with unfamiliar ones, such as Python, who emerged despite the will of the earth (Met. 1, 437-440): $:^{105}$

partimque figuras rettulit antiquas,

partim nova monstra creavit.

Illa quidem nollet, sed te quoque, maxime Python,

tum genuit, populisque novis, incognita serpens,

terror eras:

He brought some according to old forms,

And created others like new exotic animals.

In fact he did not want those animals, and you too,

Especially Python came, the unknown snake,

And terror spread within new humans.

These changing forms, which are a different kind of creation, are made by the gods. Ovid confirms in his work that the gods have overseen and changed this creation. Kovacs points out that many epic heroes have been metamorphosed to birds, animals, trees and flowers by gods. ${ }^{106}$ The gods

${ }^{104}$ Wheeler, S.M. (1995), p. 116.

${ }^{105}$ Fletcher, K.F.B. (2010), p. 211.

${ }^{106}$ Kovacs, D. (1987), Ovid, Metamorphoses.1.2, CQ, vol. 37, pp. 459, 465. 


\section{Ahmed Fahmy Abdel Gawad}

specified forms for human and immortal semi -divinities; just as they created human beings, they made animals. ${ }^{107}$

\section{Conclusions}

1- The story of Deucalion and Pyrrha in Ovid's epic is more complete than that of Vergil about the epic of human creation. If we sometimes feel that some Vergilian details are the exponents of the whole Ovid version, we can not forget that Deucalion in Vergil's epic is almost a reference only mentioned in Georgics without any narration of his legend.

2- Based on the will of god and out of the scattered blood of giants' sons, creatures emerged, being the first creation. They had the characteristics of humans and urbanized the earth. However, traces of blood sheds from which human beings were created appeared; that is why arrogance and cruelty overshadowed this creation.

3- The flood covered the whole earth, but did not kill all creatures; there were semi -gods, spirits, nymphs, satyrs, and gardens in the forests and hills, which had no place in the sky. So, Jupiter must have created a life for them on earth.

4- Deucalion and Pyrrha are the nucleus of the creation of the new human race of stones; this genesis is characterized by hardness and roughness from the beginning.

5- According to Ovid in "Metamorphoses", after the end of the flood, the earth created all other beings on their own; there were familiar patterns and unfamiliar ones, such as Python, that terrified human hearts.

6- The contradictions in Ovid's account of the Flood are largely conventional, but they represent a model of Ovid's optimism. These contradictions reveal absurdity while at the same time dominate the world in a spirit of greatness; the world is stained with chaos everywhere.

107 Garlic, O. (1991), Vernacular and Latin Readings of Ovid's Metamorphoses in the Middle Ages, University of California, p. 135. 


\section{$\underline{\text { Abbreviations }}$}

AJPh: American Journal of Philology.

CA: Classical Antiquity.

CJ: Classical Journal.

$\mathrm{CPh}$ : Classical Philology.

CQ: Classical Quarterly.

FR: The French Review.

G\&R: Greece \& Rome.

HSPh: Harvard Studies in Classical Philology.

ICS: Illinois Classical Studies.

JHC: A Journal of Humanities and the Classics.

MDTC: Materiali e Discussioni per L'analisi dei Testi Classici.

MQ: Milton Quarterly.

NLH: New Literary History

SPh: Studies in Philology.

TAPhA: Transactions and Proceedings of the American

\section{Bibliografy}

\section{Sources}

Apollodorus' Library and Hyginus' Fabulae, (2007), Two Handbooks of Greek Mythology, $1^{\text {st }}$ Edition، translated by R. S.Smith and S.M. Trzaskoma, USA.

Apollonius Rhodius, (2009), Argonautica. Edited and translated by William H. Race, (L.C.L).

Cicero, (1933), On the Nature of the Gods. Academics. Translated by H. Rackham, (L.C.L).

Diogenes Laertius, (1925), Lives of Eminent Philosophers, Volume II: Books 6-10. Translated by R. D. Hicks, (L.C.L).

Hesiod, (2007), Theogony. Works and Days. Testimonia. Edited and translated by Glenn W. Most, (L.C.L).

Homer, (1924), Iliad, Volume I: Books 1-12. Translated by A.T. Murray. Revised by William F. Wyatt, (L.C.L).

(1925), Iliad, Volume II: Books 13-14. Translated A.T. Murray. Revised by William F. Wyatt, (L.C.L).

Horace, (2004), Odes and Epodes, Edited and translated by N. Rudd, (L.C.L). 


\section{Ahmed Fahmy Abdel Gawad}

Juvenal, Persius, (2004), Juvenal and Persius. Edited and translated by Susanna Morton Braund, (L.C.L).

Lucretius, (1924), On the Nature of Things. Translated by W.H.D. Rouse. Revised by Martin F. Smith, (L.C.L).

Ovid, (1914), Heroides. Amores. Translated by Grant Showerman. Revised by G. P. Goold, (L.C.L). , (1916), Metamorphoses, Volume I: Books 1-8. Translated by Frank Justus Miller. Revised by G.P. Goold, (L.C.L). , (1929), The Art of Love and Other Poems, $2^{\text {nd }}$ edition, Translated by G.H. Mozley, (L.C.L).

, (1931), Fasti. Translated by James G. Frazer. Revised by G. P. Goold, (L.C.L).

Pausanias, (1935), Description of Greece, Volume IV, Books 8. 17-35 ,Translated by W. H. S. Jones, (L.C.L).

Pindar., (1994), Olympian Odes. Pythian Odes. Edited and translated by William H. Race ‘(L.C.L).

Plato, (2013), Republic, Volume II: Books 6-10. Edited and translated by Christopher Emlyn-Jones, William Preddy، (L.C.L).

Virgil, (1916), Eclogues. Georgics. Aeneid: Books 1-6 .Translated by H. Rushton Fairclough. Revised by G. P. Goold, (L.C.L).

\section{$\underline{\text { Books \& Articles }}$}

Anderson, W.S. (1989), Lycaon: Ovid's Deceptive Paradigm in Metamorphoses 1, ICS 14, pp. 91-101.

Anthony, S.K. (2000), Ovid's Metamorphoses, A Complete English translation and Mythological index, London.

Barnes, C.L.H. (2007), Reading after Actium: Vergil's Georgics, Octavian and Rome by Christopher Nappa , Vergilius , vol. 53, pp. 185-191.

Berens, E.M. (2009), Myth and Legends of Ancient Greece and Rome, Amsterdam.

Born, L.K. (1934), Ovid and Allegory, Speculum, vol. 9, pp. 362-379

Brown, R.D. (1990), The Homeric Background to a Vergilian Repetition (Aeneid. 1. 744-3.516), AJPh, vol. 111, pp. 182-186.

Putter, A. (1997), Sources and Backgrounds for Descriptions of the Flood in Medieval and Renaissance Literature, SPh, vol. 94, pp. 137- 159.

Casali,S.(2006), Reading after Actium: Vergil's Georgics, Octavian and Rome by Christopher Nappa, $A J P h$, vol. 127, pp. 611-615. 
Fletcher, K.F.B. (2010), Ovidian "Correction" of the Bible Flood, $C P h$, vol. 105 , pp. 209-213.

Green, M. (2001), Softening the Stony: Deucalion, Pyrraha, and the Process of Regeneration in "Paradise Lost", $M Q$, Vol.35, p.9-21.

Griffin, A.H.F. (1977), Ovid's Metamorphoses, $G \& R$, vol. 24, pp. 57-70. , (1992), Ovid's Universal Food, Hermathena, No.152, pp.3958.

Garlic, O. (1991), Vernacular and Latin Readings of Ovid's Metamorphoses in the Middle Ages, University of California.

Haig, S. (1965), Andre Pieyre de Mandiargues and "Les Pierreuse ", FR, vol. 39, pp. $275-280$.

Kitchell, K.F. (1993), The View From Deucalion's Ark: New Windows on Antiquity, $C J$, vol. 88, pp. 341-357.

Kovacs, D. (1987), Ovid, Metamorphoses. 1.2, CQ, vol. 37, pp. 458-465.

Lamacchia, R. (1960), Ovidio Interprete di Virgilio, Maia 12, pp. 310-310.

Lorenz, S. (2004), Dignae Iove Irae: Ovids Deucalion und Pyrrha in Juvenals erster Satire, Latomus 63, pp. 892-904.

Mckim, R. (1985), Myth against Philosophy in Ovid's Account of Creation, CJ, vol. 80, pp. 97-108.

Miller, J.F. (1993), Ovidian Allusion and the Vocabulary of Memory, MDTC, vol. 30, pp. 153-164.

Nappa, Ch. (2002), Experiens Laborum: Ovid Reads the 'Georgies " , Vergilius, vol. 48, pp. 71-87.

Newby, Z. (2012), The Aesthetics of Violence: Myth and Danger in Roman Domestic Landscapes, $C A$, vol. 31, pp. 349-389.

Olmsted, W. (1996), On the Margins of Otherness: Metamorphosis and Identity in Homer, Ovid, Sidney, and Milton, $N L H$, Vol. 27, No. 2, pp. 167-184

Paschalis, M. (2001), Semina Ignis: The Interplay of Science and Myth in the Song of Silenus, $A J P h$, vol. 122, pp. 201-222.

Putter, Ad. (1997), Sources and Backgrounds for Descriptions of the Flood in Medieval and Renaissance Literature, $S P h$, vol. 94, pp. 137-159.

Robbins, F.E. (1913), The Creation Story in Ovid Met.1, CPh, vol. 8, pp. 401-414.

Ryder, T.B. (1967), Ovid, The Flood and Ararat, $G \& R$, vol. 14, pp. 126129.

Segal, Ch. (2001), Jupiter in Ovid's ' Metamorphoses", Arion, JHC, vol. 9, pp. 78-99. 


\section{Ahmed Fahmy Abdel Gawad}

Segal, Ch. (1968), Homer, Vergil, Ovid, TAPHA, vol. 99, pp. 419- 442.

Stirrup, B.E. (1976), Ovid's Narrative Technique: A Study in Duality, Latomus.35, pp. 97-107.

Taylor, AE (1928), A commentary on Plato's Timaeus. Oxford.

Thomas, R.E. (1986), Virgil's Georgics and the Art of Reference, $H S P h$, vol. 90 , pp. 171-198.

Watkins, O.D. (1983), Ovid ,"Metamorphoses", 8, 365-368, Latomus . 42, pp. 135-138.

Olmsted, W. (1996), (1996), On the Margins of Otherness: Metamorphosis and Identity in Homer, Ovid, Sidney, and Milton, $N L H$, Vol. 27, No. 2, pp. $167-184$

Wheeler, S.M. (1995), Imago Mundi: Another View of the Creation in Ovid's Metamorphose, $A J P h$, vol. 116, pp.95-121. 